\title{
TOWARD A "NEW DEAL" FOR COPYRIGHT IN THE INFORMATION AGE
}

\author{
Pamela Samuelson*
}

Digital Copyright. By Jessica Litman. Amherst, New York: Prometheus Books. 2001. Pp. 208. Cloth, \$25.

\section{INTRODUCTION}

Jessica Litman ${ }^{1}$ believes the public needs a very good copyright lawyer, and if I have not mistaken her intentions, she is volunteering for the job (pp. 70-73). A century of Congressional deference to industry-negotiated compromises has produced, she argues, a copyright law that is both incomprehensible and unfair. ${ }^{2}$ This incomprehensibility might be tolerable if copyright law governed only commercial relations among industry participants, all of whom have copyright counsel. To the extent that copyright law applies to the conduct of ordinary persons, ${ }^{3}$ its incomprehensibility presents serious difficulties. ${ }^{4}$ Moreover, to the extent that copyright law makes illegal many ordinary activities of individuals ${ }^{5}$ - for example, making private copies of music for oneself or to share with a friend or forwarding articles to friends via the Internet - it has become unfair as well (pp. 19, 28). As the public's copyright lawyer, Jessica Litman advises us not to accept the current deal (p. 20). In Digital Copyright, she outlines a framework for a copyright law that would be a new and better deal for the public and would be short, comprehensible, and normative in character (pp. 180-84).

While Litman does not advocate lawlessness until the new deal has been adopted, she makes clear that she does not object to widespread noncompliance with copyright law in the meantime. In fact, the pub-

\footnotetext{
* Chancellor's Professor of Law and Information Management, University of California at Berkeley. B.A. 1971, University of Hawaii; J.D. 1976, Yale. - Ed.

1. Professor of Law, Wayne State University Law School.

2. Litman has harsh words for current copyright law, which she characterizes as "complex, internally inconsistent, wordy, and arcane," as well as unfair. P. 19.

3. See infra notes 18-25 and accompanying text for a discussion of the application of copyright to ordinary people.

4. Litman discusses these difficulties in chapters 4,8 , and 12 .

5. See infra notes 21-25 and accompanying text for more details as to Litman's argument.
} 
lic's noncompliance with strict copyright rules fuels Litman's hopes for eventual change (p. 194). People do not obey laws they don't believe in, she argues, and governments find it difficult to enforce laws that lack public support (p. 112). Therefore, if something has to change, Litman believes it will be copyright law, not the behavior of the public. Digital Copyright is Litman's paean to a future in which copyright will once again be a component of the nation's enlightened information policy.

As will become evident (if it isn't already), Litman's perspective on copyright law and my own are quite similar. Yet Litman's work is distinctive in several respects: in her informed historical perspective on copyright law and its legislative policy; her remarkable ability to translate complicated copyright concepts and their implications into plain English; her willingness to study, understand, and take seriously what ordinary people think copyright law means; and her creativity in formulating alternatives to the present copyright quagmire. ${ }^{6}$ Perhaps it is too much to ask that Digital Copyright also provide concrete strategies for transforming the copyright legislative process so that the new deal of copyright would become feasible. It is difficult, however, to come away from this book without wishing Litman had the ingenuity to be the public's chief strategist for achieving the new deal as well.

\section{Copyright Policy AND THE Legislative Process}

Much of Litman's career has been devoted to studying and writing about the legislative process for making copyright policy. ${ }^{7}$ She is one of the few living persons familiar with the entire legislative history some twenty years' worth of materials - of the Copyright Act of 1976. One might initially have thought that the past hundred years of copy-

6. This is not to say that Litman is the only creative copyright scholar of the day. In fact, the field of copyright scholarship is alive with talent, much of which focuses on digital copyright issues. See, e.g., LAWRENCE LESSIG, CODE AND OTHER LAWS OF CYBERSPACE 122-41 (2000); Yochai Benkler, Free As the Air to Common Use: First Amendment Constraints on the Enclosure of the Public Domain, 74 N.Y.U. L. REV. 354 (1999); James Boyle, The Politics of Intellectual Property: Environmentalism for the Net?, 47 DUKE L.J. 87 (1997); Julie E. Cohen, Lochner in Cyberspace: The New Economic Orthodoxy of "Rights Management," 97 MICH. L. REV. 462 (1998); Niva Elkin-Koren, Copyright Law and Social Dialogue on the Information Superhighway: The Case Against Copyright Liability of Bulletin Board Óperators, 13 CARDOZO ARTS \& ENT. L.J. 345 (1995); Mark A. Lemley, Dealing With Overlapping Copyrights on the Internet, 22 U. DAYTON L. REV. 547 (1997); Glynn S. Lunney, Jr., The Death of Copyright: Digital Technology, Private Copying and the Digital Millennium Copyright Act, 87 VA. L. REV. 813 (2001); Neil W. Netanel, Copyright and a Democratic Civil Society, 106 YALE L.J. 283 (1996). I confess to contributing to this discussion as well, although often in venues outside of the law review literature. See, e.g., Pamela Samuelson, Intellectual Property Rights and the Global Information Economy, 39 COMM. ACM 23 (Jan. 1996); Pamela Samuelson, The Copyright Grab, 4.01 WIRED 134 (Jan. 1996).

7. See, e.g., Jessica Litman, Copyright, Compromise, and Legislative History, 72 CORNEll L. REV. 857 (1987); Jessica Litman, Copyright Legislation and Technological Change, 68 OR. L. REV. 275 (1989). 
right lawmaking would be a very abstruse subject with little or no relevance to current digital copyright debates. In Digital Copyright, Litman shows that this history has considerable significance and, in fact, is at the heart of the problem.

A key legislative development of the past century is the evolution of a pattern of congressional activity on making copyright law and policy. About one hundred years ago, says Litman,

Congress got into the habit of revising copyright law by encouraging representatives of the industries affected by copyright to hash out among themselves what changes needed to be made and then present Congress with the text of appropriate legislation. By the 1920's, the process was sufficiently entrenched that whenever a member of Congress came up with a legislative proposal without going through the cumbersome prelegislative process of multiparty negotiations, the affected industries united to block the bill. (p. 20)

Litman observes that this process "generates legislation with some predictable features" (pp. 23-24). For one thing, established industry players will not support any bill that would leave them worse off than under current law. Second, these players will frequently characterize the state of current law as though it already favors their position, the current law being the baseline against which negotiations will occur. Third, negotiations tend to result in very specific and detailed rules that resolve the main concerns of the players at that stage of the industry's history. The first two of these features tend to tilt copyright law in the direction of ever stronger protection, while the third contributes to the law's incomprehensibility. In addition, "[t]his type of drafting process makes it exceedingly difficult to speak of legislative intent if by legislative intent one means the substantive intent of members of Congress" or to discern "any overall purpose pervading the text of the statute" (p. 53).

Delegation of legislative drafting to affected industry groups has some undeniable benefits. Copyright industry representatives obviously have a much better understanding of the likely impacts of particular rules for their industry than do members of Congress (p. 61). Insofar as the affected industry groups are able to reach consensus on legislation, Congress can have confidence that this will produce workable results. Congress may also assume that the resulting legislation must adequately balance the interests of the affected parties; otherwise the compromise would not have been achieved. ${ }^{8}$ Delegation of authority to the industry thus not only takes advantage of industry expertise, but it also makes lawmaking on copyright issues politically feasible (p. 73).

8. Litman says that "while it is easy to claim that the interplay among all of the interests affected by copyright provides a proxy for the public interest, the statute that this interplay produces demonstrates that this isn't so." $P .73$. 
This pattern of industry-negotiated and industry-drafted legislation also has negative consequences. Among the most serious is that emerging industries - along with those that have yet to be invented - do not have a seat at the negotiating table, and hence their interests will generally not be taken into account in the process of crafting revisions to the law (p. 62). Moreover, to the extent that established industry players perceive emerging industries as threats to their hegemony, they will be inclined to craft legislation granting them advantages over these rivals (pp. 144-45).

Litman gives both past and contemporary examples of this phenomenon. In the early days of the sound recording and motion picture industries, for example, these nascent industries did not have a seat at the negotiating table, and they consequently had no influence over rules adopted without attention to their interests or in order to disadvantage them (p. 39). Now that these industries have become established players, they exercise their considerable clout in the legislative process to disadvantage upstart Internet-savvy rivals, as evidenced in the Digital Millennium Copyright Act ("DMCA"). ${ }^{9}$

Litman explains that disadvantaging upstart rivals is much easier now than it was thirty years ago because of a major restructuring of U.S. copyright law in 1976. The Copyright Act of 1909 and its predecessor statutes granted different sets of exclusive rights to different kinds of works. ${ }^{10}$ The narrow crafting of the 1909 Act's exclusive rights provisions often meant that a new technology or industry escaped liability because Congress had not anticipated it. ${ }^{11}$ The law was amended numerous times to take new technologies or industries into account, sometimes the goal being to provide the new industry with copyright protection ${ }^{12}$ and sometimes to extend the rights of an existing industry so that the emergent industry had to pay for its use of copyrighted materials..$^{13}$ The Copyright Act of 1976 adopted a far simpler structure in which virtually all works were accorded the same set of five exclusive rights, ${ }^{14}$ which were qualified by a series of very spe-

9. Pub. L. No. 105-304, 112 Stat. 2860 (1998), the relevant provisions of which are now codified at 17 U.S.C. $\$ \S 1201-04$. The DMCA is discussed at length in Digital Copyright, particularly in chapter 9 .

10. See 17 U.S.C. $\$ 1$ (repealed 1976).

11. See, e.g., White-Smith Music Pub. Co. v. Apollo Co., 209 U.S. 1 (1908) (holding that piano roll recordings did not infringe copyright in musical compositions).

12. See, e.g., Craig JoyCE ET AL., Copyright LAW \& 1.04, at 11 (2d ed. 1991) (noting that motion pictures were added to the subject matter of copyright in 1912).

13. See pp. 39-40 (explaining that copyright law was amended to give owners of copyrights in musical compositions the right to control mechanical reproductions of their works in sound recordings).

14. 17 U.S.C. $\$ 106(2000)$. Some works (e.g., sound recordings) enjoy some but not all of these exclusive rights. See id. $\$ \S 106(4), 106(5)$. Some works (e.g., sound recordings) have special exclusive rights privileges. See id. $\S \$ 106(6), 106$ A. 
cific exceptions ${ }^{15}$ Libraries, veterans' groups, and nonprofit horticultural organizations were among the groups that managed to persuade Congress to exempt some of their activities from copyright law. ${ }^{16}$

Litman argues that the 1976 Act dramatically changed copyright law's baseline presumption from one in which upstarts often found shelter because existing rights were narrowly crafted to one in which upstarts were likely to run afoul of a broad exclusive right. In the post1976 era, upstarts rarely qualify for an existing exception because the need for such an exception was not recognized in 1976 (p. 37). This pattern of broad rights and narrow limitations is replicated in the new DMCA rules outlawing acts of circumvention of technical measures used by copyright owners to protect access to their works and outlawing circumvention technologies. ${ }^{17}$

As serious as may be the exclusion of emerging industries from the copyright lawmaking process and the impact of the restructured copyright law for emerging industries, this is not Litman's main concern in Digital Copyright. Rather, her primary concern is with the impact of the current law on the activities of ordinary people, particularly as regards use of digital information on the Internet. The public has also been excluded from the copyright legislative process. To the extent that copyright law applies to private activities of members of the public, this exclusion is unacceptable (p. 116). The broad rights/narrow exceptions structure of the 1976 Act arguably disadvantages members of the public just as it does emerging industries. Moreover, the copyright industry's sense of ownership of the copyright policy process - and Congress's acquiescence in this, owing at least in part to their being the source of generous campaign contributions - has erected a serious obstacle to reforming the current legislative process. ${ }^{18}$

\section{17 U.S.C. $\S \S 107-22(2000)$.}

16. See id. $\S \S 108$ (granting exception for library and archival uses of copyrighted works), 110(6), 110(10) (exempting some performances of some copyrighted works in the course of functions sponsored by nonprofit horticultural organizations or veterans groups). Only the fair use provision has sufficient generality that emerging or future industries can invoke it as a shelter for their activities. See id. $\S 107$; see also infra note 66 for examples of the successful assertion of fair use as a shelter for new technologies.

17. See 17 U.S.C. $\$ \S 1201(\mathrm{a})(1)(\mathrm{A})$, (a)(2), (b)(1) (2000) (granting broad rights); 1201(c)-(j) (containing narrow exceptions).

18. Litman mentions the influence of copyright industry campaign contributions. P. 62 . Litman gives this example of the copyright industry's sense of entitlement to control the copyright policy agenda:

Allen Adler, the chief lobbyist for the book publishers group, was frankly resentful that the Commerce Committee had dared to insist on exercising jurisdiction in the first place [during the legislative process leading up to enactment of the DMCA]. He found it outrageous that Commerce Committee members, who had far less experience on copyright bills than their colleagues on the House and Senate Judiciary Committees, would insist that the content community make a deal that would satisfy libraries, universities, or consumer electronics manufacturers .... [C]ontent lobbyists made the rounds, characterizing library, university, 
The public can be forgiven for thinking that copyright law simply doesn't apply to their ordinary activities. After all, most of the exclusive rights of the 1976 Act specifically regulate public acts - the right to control distribution of copies to the public and public performances and displays - not private ones. ${ }^{19}$ Private noncommercial copying of copyrighted materials has generally been deemed fair use following the Supreme Court's Sony Betamax ruling under which private noncommercial copying is presumed to be fair. ${ }^{20}$ Insofar as the public understands copyright law, the principal norm they grasp is that it is forbidden to commercialize someone's work, but not to make private, noncommercial uses of it. If the public's conception of copyright law aligns with what the law actually provides, there should be no problem.

So, either something has dramatically changed to put the public so much at risk or Litman has gone off the deep end. Litman argues that the digitalization of information and the rise of global networks such as the Internet have presented an occasion for a transformed conception of copyright law's scope (pp. 14, 25-26). Notwithstanding the Sony Betamax decision, copyright industries regard private copying of copyrighted materials as infringements, ${ }^{21}$ especially when the works are available in digital form, because of the new licensing models under development to charge for such uses. ${ }^{22}$ If private copying threatens copyright industry markets, the fair use defense arguably crumbles. ${ }^{23}$

Moreover, in an act of "breathtaking hubris" (p. 30), copyright industry supporters have embraced the view that copyright owners are entitled to control all access to and uses of copyrighted works in digital form because each act involves reproductions of the work in the ran-

and consumer electronics proposals as scandalous, unprecedented, and unabashedly greedy. P. 140

19. 17 U.S.C. $\S 106(3)-(5)$ (2000). Litman briefly mentions these limitations. P. 71.

20. Sony Corp. of Am. v. Universal City Studios, 464 U.S. 417, 451 (1984). The Court went on to say that this presumption should only be overcome if there was proof of a meaningful likelihood of harm to copyright markets. Id. I will refer to this case in the text as Sony Betamax.

21. See, e.g., COMPuter ScI. \& Telecomms. BD., NAT'L RESEARCH COUNCIL, ThE DigITAL DILEMMA: INTELLECTUAL PROPERTY IN THE INFORMATION AGE 129-39 (2000) [hereinafter DigiTAL DilemMA] (discussing private copying); Jane C. Ginsburg, Putting Cars on the "Information Superhighway": Authors, Exploiters, and Copyright in Cyberspace, 95 COLUM. L. REV. 1466 (1995).

22. See, e.g., Report of Working Group on Intellectual Property Rights of Information Infrastructure Task Force, Intellectual Property Rights and the National Information Infrastructure 82 (Sept. 1995) [hereinafter White Paper] (arguing that there is less need for fair use because of the emergence of new licensing models for digital information).

23. The fair use provision directs courts to consider harm not only to actual markets but also to potential markets for the copyrighted work. See 17 U.S.C. $\$ 107$ (2000); Am. Geophysical Union v. Texaco, Inc. 60 F.3d 913 (2d Cir. 1994) (discussing emergence of licensing system for photocopying weighed against fair use defense). 
dom access memory of a computer. ${ }^{24}$ They also believe that digitalization puts an end to copyright's "first sale" doctrine, which has allowed sharing of one's CD with a friend or reselling a book after finishing it, since to redistribute a digital copy of a work requires making a copy in the transmission process. ${ }^{25}$ Copyright industries are experimenting with technical measures to prevent unauthorized private copying of copyrighted materials, ${ }^{26}$ and they convinced Congress to pass the DMCA, which grants them rights to control circumvention of these technical measures and the making and distribution of technologies capable of circumvention. ${ }^{27}$

This lays the groundwork for the "pay-per-use" economy in digital information that some copyright industries seem to desire (p. 27). Use of technical measures makes the public's access to ideas and information "contingent on the copyright holders' marketing plans, and puts the ability of consumers to engage in legal uses of the material in those texts within the copyright holder's unconstrained discretion. In essence, that's an exclusive right to use" (p. 83). Litman's principal objection is that this transformation of copyright was accomplished by a "sleight of hand," not an informed debate on the merits with an opportunity for meaningful public input (p. 86). To the extent that copyright has been so transformed, Litman would agree with the copyright industries that the public does not comply with the law. Her preferred solution, however, is not beefed-up enforcement or copyright reeducation camp for the public, ${ }^{28}$ but rather a good copyright lawyer to represent the public's interests. Much of Digital Copyright is given over to explaining what the public's copyright lawyer ought to do to turn things around. ${ }^{29}$

24. Digital Dilemma, supra note 21, at 140-44; White Paper, supra note 22, at 65-66.

25. White Paper, supra note 22 , at $90-95$ (arguing that the first sale rule does not apply to sharing of digital information). The first sale right limits the distribution right, not the reproduction right, so insofar as sharing a digital copy involves reproduction, that copying is not covered by the first sale privilege of 17 U.S.C. $\$ 109$ (2000). Litman expresses dismay about the loss of first sale rights. Pp. 81-82.

26. See, e.g., Digital Dilemma, supra note 21, at 153-71.

27. 17 U.S.C. $\$ 1201$ (2000). Litman recounts the history of the enactment of the DMCA in chapter 9 of Digital Copyright. P. 114.

28. Litman observes that the public has been resistant to copyright education efforts.

29. Being the public's copyright lawyer is, in Litman's view, the job of Congress. P. 74 . Litman believes, however, that "Congress lacks the interest, expertise, and institutional memory to represent the public on this particular project, and has found significant political benefits in deferring to the interests the legislation affects." P. 74. Congress also has its own copyright lawyer to draw upon, namely, the Register of Copyrights whose Office is part of the Library of Congress.

Unfortunately the Copyright Office has tended to view copyright owners as its real constituency and has spent the past ten years moving firmly into the content industry's pocket. The reasons are unexceptional: The office has a limited budget, and relies on the goodwill of its regular clients. Copyright Office policy staff often come from and return to law firms that 


\section{CAN THE BREAKDOWN OF THE COPYRIGHT LEGISLATIVE AND POLICY PROCESS BE REPAIRED?}

The breakdown of the copyright legislative policy process leads

Litman to imagine a role for the public's copyright lawyer in

construct[ing] a copyright law that affords members of the public the opportunity to read, see, hear, and otherwise experience, download, buy, borrow, and keep copies of all or at least most of the works that are out there, while according ample compensation to the authors and publishers of copyrighted works, and encouraging them to produce and disseminate as many copyrighted works as they are able to. (pp. 72-73)

The revised law should, she thinks, "be about three pages long, should strike more folks than not as more fair than not, and should be sufficiently intuitive to appeal to schoolchildren" (p. 73). Litman then sets forth the principal norms that she thinks should be embodied in a revised copyright law for an information age.

Litman recommends jettisoning the reproduction right of current copyright law because digital information cannot be used without making copies, and hence, the reproduction right is no longer a useful mechanism by which to distinguish activities that copyright owners should be able to control and those that they should not. ${ }^{30}$ Instead, she suggests that copyright owners should have an exclusive right to control commercial exploitations of their works as well as a right to control large-scale interferences with such commercial operations: ${ }^{31}$ She

regularly represent copyright owners. Perhaps most importantly, the Copyright Office relies

on the copyright bar to protect it from budget cuts and incursions on its turf. P. 74 .

Litman might have invoked public choice theory to explain why Congress and other government entities have been so receptive to copyright industry concerns, but this is not her wont.

30. P. 180. A recent report of the National Research Council makes a similar observation about the reproduction right. See DIGITAL DILEMMA, supra note 21 , at $140-45$. It is worth noting that copyright law protects more than digital works, and as to other works, the reproduction right may continue to be useful. Litman does not discuss whether repeal of the reproduction right or adoption of a narrower set of exclusive rights is consistent with treaty obligations the United States has under the Berne Convention and the Agreement on Trade-Related Aspects of Intellectual Property Rights. See Berne Convention for the Protection of Literary and Artistic Works, Sept. 9, 1886, as last revised at Paris, July 24, 1971; see also Final Act Embodying the Results of the Uruguay Round of Multilateral Trade Negotiations, Apr. 15, 1994, reprinted in THE RESULTS OF THE URUGUAY ROUND OF Multilateral Trade Negotiations - THE LEgal TeXTs 2-3 (Gatt Secretariat ed., 1994) [hereinafter RESUlTS OF URUGUAY Round]; Marrakesh Agreement Establishing the World Trade Organization, Apr. 15, 1994, Annex 1C: Agreement on Trade-Related Aspects of Intellectual Property Rights, reprinted in RESULTS OF URUGUAY ROUND, supra, at 6-19, 365-403.

31. Pp. 180-81. This might mean, for example, that Napster would be liable for its interference with the recording industry's commercialization of sound recordings, although individual user sharing of music would not give rise to liability. P. 181 . But see infra note 35 and accompanying text (suggesting that Napster should not have been liable for copyright infringement). 
trusts courts to engage in common law decisionmaking to apply these rules in light of a revised law's normative purposes. ${ }^{32}$ Litman proposes a statutory affirmation of the public's rights in copyright, including rights to access, read, view, and listen to publicly available works; to cite, extract, and re-use facts and ideas they contain; and, if necessary, to circumvent technical protections to access facts and ideas. ${ }^{33}$ Litman would return copyright law to the era in which this law was conceived as a bargain under which copyright owners get assurance they will be compensated for making their works available in exchange for which the public would get access to and the ability to make reasonable uses of the works. ${ }^{34}$

Although articulating a framework for a new deal for copyright is an important step toward achieving the goal, Litman proffers few ideas about how the copyright policy process itself might be reformed. At one point, she posits the existence of a hypothetical benevolent despot and explains how the despot might configure copyright law if its goal was to promote the development of new technologies (pp. 172-73). Such a despot would permit the emergence of innovative, Internet-based technologies, such as Napster and MP3.com, for disseminating music free from copyright controls. ${ }^{35}$ Litman points to several historical examples to illustrate the soundness of such a decision, explaining that some major copyright industries — including the sound recording, cable television, and videocassette industries - began in the shelter of copyright limitations. ${ }^{36}$. Of course, Litman does not really

32. P. 181. Litman believes that the highly specific exceptions in the current copyright law could then be repealed as unnecessary. P. 182. While I find those exceptions as unreadable as Litman does, I do not object to their continued presence in the copyright statute because they are workable accommodations for the affected industries and do not impact the public.

33. Pp. 175-84. Litman would not allow the public's rights to be overridden by contractual provisions or technical measures aiming to undermine them. Pp. 175-84. Oddly enough, Litman does not suggest a reaffirmation of the fair use principle, even though it often limits the scope of copyright as to clearly commercial activities. See, e.g., Campbell v. Acuff-Rose Music, Inc., 510 U.S. 569 (1994) (holding that 2Live Crew's commercial sound recording of a "Pretty Woman" rap parody qualified for fair use). Litman also does not mention the duration of copyright she thinks is appropriate.

34. Chapter 5 discusses changing concepts of copyright. Years ago, copyright was thought to provide a limited monopoly to authors as a quid pro quo for benefits to society. P. 78. A more recent conception is that copyright is a property right that gives authors and publishers the right to control all uses of their works. P. 81.

35. See A\&M Records, Inc. v. Napster, Inc., 239 F.3d 1004 (9th Cir. 2001) (service that allowed users to share copies of MP3 files via the Internet was liable for indirect copyright infringement); UMG Recordings, Inc. v. MP3.com, 92 F. Supp. 2d 349 (S.D.N.Y. 2000) (making copies of sound recordings for service enabling users to listen to previously purchased music held to be copyright infringement).

36. P. 173. The Supreme Court twice ruled that cable television retransmission of broadcast signals did not infringe the public performance right of copyright law, even though it was clearly a commercial operation. See Teleprompter Corp. v. Columbia Broad. Sys., 415 U.S. 394 (1974); Fortnightly Corp. v. United Artists Tele., 392 U.S. 390 (1968). Eventually, the public performance right was extended to encompass cable retransmission of broadcast 
advocate the appointment of a benevolent despot. The suggestion is just a device for leaping over the broken policy process and offering an alternative copyright policy for discussion.

Apart from this, Litman says only that "consumers' widespread noncompliance [with strict copyright norms] offers a very real ray of hope." ${ }^{37}$ If "[p]eople don't obey laws they don't believe in" (p. 195) and if "[g]overnments find it difficult to enforce laws that only a handful of people obey" (p. 195), then she believes that copyright law will eventually have to change or become irrelevant. ${ }^{38}$ For her a lesson of the Napster controversy is that "[i]f 137 million members of the general public copy, save, transmit, and distribute content without paying attention to the written copyright rules, those rules are in danger of becoming irrelevant" (p. 114). Yet copyright would seem very relevant if the recording industry can get injunctions not only against Napster, but against other peer-to-peer technology providers, such as Aimster and Grokster. ${ }^{39}$

It is understandable that Litman has so little confidence in Congress as an instrument of change toward a more enlightened copyright policy. After all, she knows better than anyone else the history of copyright industry domination of the legislative process. Moreover, her participation in the legislative struggles over the DMCA left her even more disillusioned than her academic study of the subject. The DMCA, she asserts, "is substantially more pernicious than the bill originally proposed by the ... White Paper" (p. 145). The White Paper bill was "breathtakingly expansive but it was. short. It didn't improve the copyright law's general level of incomprehensibility but it didn't exacerbate it either" (p. 145). The DMCA, by contrast, is "riddled with ambiguities, internal inconsistencies, contradictions, and obfusca-

programming under one of the negotiated provisions that Litman criticizes. See 17 U.S.C. $\$ \S$ 101,111 (2000) (the former defining "public performance" as including transmissions, and the latter allowing cable systems' secondary transmission of broadcast programs).

37. P. 194. Litman adds:

If someone claims that a law provides such and such, but such and such seems to make no sense, then perhaps that isn't really the law, or wasn't intended to be the way the law worked, or was the law at one time but not today, or is one of those laws, like sodomy law, that it is OK to ignore. Our current copyright statute has more than merely a provision or two that doesn't make a lot of sense; it's chock full of them.

P. 114 .

38. Pp. 111-14. Litman makes a passing reference to "copyright police," p. 194, but she does not seem to think it likely that serious attempts will be made to enforce copyright laws against individual users.

39. See A\&M Records, 239 F.3d 1004 (holding injunction overbroad but remanding for narrower drafting. See, e.g., Brad King, Aimster the Latest to Chime In, WIRED, Nov. 14, 2001, available at http://www.wired.com/news/mp3/0,1285,48255,00.html (discussing litigation between the recording industry and Aimster); Complaint in MGM Studios, Inc. v. Grokster, Inc., available at http://www.eff.org/IP/P2P/MGM_v_Grokster/20011002mgm_v_grokster_ complaint.html (last visited Mar. 4, 2002). 
tory prose" (p. 142). There is, Litman intimates, no Mr. Smith in Congress whose goal is to bring about a more balanced copyright policy.

While I am no admirer of the DMCA, I see in it more of an attempt at balanced copyright law than she does. For one thing, the DMCA soundly rejected the copyright industry's position that Internet service providers ("ISPs") should be strictly liable for copyright infringement of users. ${ }^{40}$ Instead, Congress enacted a broad set of safe harbor provisions pertaining to the transmission, storage, and caching of copyrighted information, as well as protecting information location tools, such as search engines, against unwarranted claims of infringement. ${ }^{41}$ This was a victory not only for ISPs and Internet firms, but also for members of the public. ${ }^{42}$

Second, an important backdrop to the DMCA legislative debate was a digital copyright treaty negotiated in Geneva in December 1996. This treaty repudiated numerous highly protectionist provisions initially supported by the Clinton Administration and adopted instead a balanced set of copyright rules. ${ }^{43}$ Congressional ratification of this balanced treaty was in the public interest and is very much part of the current digital copyright policy landscape. Litman only briefly mentions the treaty and its far more balanced copyright rules (pp. 128-29). Third, while I agree that the DMCA's anti-circumvention provisions are in some respects worse than the White Paper's proposal, ${ }^{44}$ they are

40. See, e.g., White Paper, supra note 22, at 114-24 (asserting online service providers were strictly liable for copyright infringements of their users).

41. 17 U.S.C. $\S 512(2000)$.

42. Not only did the safe harbors ensure that ISPs and Internet search engines could continue to provide useful services to Internet users free from copyright owner controls, but the DMCA also protected user privacy by providing that ISPs had no duty to monitor users and set up stiff notice and counternotice requirements so that users would be protected against vague or false claims of copyright infringement. See id. $\$ 512(\mathrm{c})(3)$, (f), (g).

43. See WIPO Copyright Treaty, adopted by the Diplomatic Conference, WIPO Doc. CRNR/DC/89 (Dec. 20, 1996). A very similar treaty was concluded on the same date concerning intellectual property protection for sound recordings. See WIPO Performances and Phonograms Treaty, adopted by the Diplomatic Conference, WIPO Doc. CRNR/DC/90 (Dec. 20, 1996); see also Agreed Statements Concerning the WIPO Copyright Treaty, adopted by the Diplomatic Conference on Dec. 20, 1996, WIPO Doc. CRNR/DC/96. See generally Pamela Samuelson, The U.S. Digital Agenda at WIPO, 37 VA. J. INT'L L. 369 (1997) (analyzing provisions in the draft treaty and the treaty finally adopted). U.S. officials initially supported provisions that would have given copyright owners the right to control temporary as well as permanent copies of works, that threatened fair use and other limitations and exceptions to copyright law, and that would have adopted a White Paper-like anticircumvention rule. The final treaty only required signatories to provide some protection against circumvention of technical measures, omitted the proposed provision on temporary copies, and included an agreed upon statement of interpretation of the treaty endorsing the continued viability of exceptions and limitations in copyright and foreseeing that new exceptions might be needed for the digital environment.

44. The White Paper did not recommend outlawing the act of circumventing technical measures. See White Paper, supra note 22, Appendix 1, at 6. The DMCA, however, makes circumventing access controls illegal. See 17 U.S.C. $\$ 1201$ (a)(1)(A) (2000). 
better in other ways. ${ }^{45}$ There may be more wiggle-room in the DMCA rules and more ambiguity in the legislative history than Litman perceives. ${ }^{46}$ Fourth, Congress has taken some heed of public interest concerns as to legislation aimed at giving copyright-like protection to factual compilations, despite strong support for the legislation from major publishers. ${ }^{47}$

While copyright industry groups will certainly continue to have influence in the copyright policy process, a great many organizations represent interests that overlap with those of the public at large, and some of them - universities and other educational institutions, consumer protection groups, scientific and technical organizations, computer industry groups, and consumer electronics manufacturers may become more effective lobbyists on copyright matters in future years. Congress might also establish something akin to the Office of Technology Assessment to provide it with independent advice about policy options when legislating on intellectual property and other issues responding to challenges presented by new technologies. ${ }^{48}$ In Congressman Rick Boucher, the public has a would-be Mr. Smith who

45. The White Paper legislation would have outlawed technologies if the primary purpose or effect was to circumvent technical measures. White Paper, supra note 22, Appendix 1 , at 6 . The DMCA makes illegal technologies that are primarily designed or produced to circumvent technical measures. 17 U.S.C. $\$ 1201$ (a)(2), (b)(1) (2000). The White Paper legislation contained no exceptions or limitations on its scope. White Paper, supra note 22, Appendix 1, at 6 . Although the DMCA has too few exceptions and limitations, at least it recognizes the legitimacy of many acts of circumvention and of making tools for circumvention. See id. $\$ 1201$ (d)-(j); Pamela Samuelson, Intellectual Property and the Digital Economy: Why the Anti-circumvention Rules Need to Be Revised, 14 BERKELEY TECH. L.J. 519, 543-46 (1999) (explaining why the DMCA needs more exceptions and limitations than it currently has). The DMCA anti-circumvention provision requires the Librarian of Congress to hold periodic hearings to determine if additional exceptions are needed and empowers the Librarian to issue rules to provide further exceptions. $I d$. $\$ 1201$ (a)(1)(B)-(C). The first set of hearings and rulemaking proceeding added two new exceptions to the anti-circumvention rules. See Exemption to Prohibition on Circumvention of Copyright Protection Systems for Access Control Technologies, 65 Fed. Reg. 64556-01 (Oct. 28, 2001) (to be codified at 37 C.F.R. pt. 2 d).

46. Courts could look to several provisions of 17 U.S.C. $\$ 1201$ (c) to limit the application of the DMCA rules. See, e.g., Samuelson, supra note 45, at 537-43 (discussing 1201(c) and other exceptions); see also Jane C. Ginsburg, From Having Copies to Experiencing Works: The Development of an Access Right in.U.S. Copyright Law, in U.S. INTELLECTUAL PROPERTY: LAW AND POLICY (Hugh Hansen ed., forthcoming June 2002) (suggesting that 1201(c) may permit some fair use circumventions).

47. See, e.g., J.H. Reichman \& Paul F. Uhlir, Database Protection at the Crossroads: Recent Developments and Their Impact on Science and Technology, 14 BERKELEY TECH. L.J. 793 (1999) (discussing two such bills H.R. 2281 and H.R. 354).

48. The Office of Technology Assessment wrote a number of reports on intellectual property issues. See, e.g., OFFICE OF TECHNOLOGY ASSESSMENT, U.S. CONGRESS, FINDING A BALANCE: COMPUTER SOFTWARE, INTEllectual PROPERTY AND THE Challenge OF TEChNological CHANGE (1992); OfFice of TEChNOlogy Assessment, U.S. CONGRESS, COPYRIGHT AND HOME COPYING: TeChNOLOGY CHALlenges THE LAW (1989); OFFICE OF TECHNOLOGY ASSESSMENT, U.S. CONGRESS, INTELLECTUAL PROPERTY RIGHTS IN AN AGE OF ELECTRONICS AND INFORMATION (1986). 
is committed to legislation restoring balance in copyright law that was lost by enactment of the DMCA. ${ }^{49}$ If the public once again becomes engaged in copyright policy issues, this may attract supporters to Boucher's bills.

Public involvement in the copyright policy process is not without precedent. In the 1980 s, while the Sony Betamax case was pending before the Supreme Court, consumer groups actively lobbied for legislation to protect personal use copying and against copyright industrysupported legislation that would have outlawed it. ${ }^{50}$ Similar lobbying in the 1990's led to enactment of a little-noticed exemption for noncommercial copying of sound recordings that Congress hoped would finally resolve the controversy about private copying of music. ${ }^{51}$ If the sound recording industry does not make digital music broadly available on reasonable terms, it is quite possible that legislation will be needed to promote broader public access to and ability to use recorded music. Senator Orrin Hatch has made clear that he will be watching developments in this area. ${ }^{52}$ Also, copyright industry groups may become overconfident and go too far in pressing their legislative agenda. The Motion Picture Association of America ("MPAA") has recently urged enactment of legislation to mandate installation of technical measures into all interactive digital devices. ${ }^{53}$ This may trigger a counter-reaction by affected industry groups and the general public, although this obviously remains to be seen.

Executive Branch developments could also help to change the policy environment. If, for example, the U.S. Department of Justice

49. See, e.g., Representative Rick Boucher (D-VA), Address at American University, Washington College of Law (Mar. 6, 2001), available at http:/www.techlawjournal.com/ intelpro/20010306boucher.asp (concerning proposals for changes to the fair use doctrine in the context of digital and Internet media). Boucher sponsored an alternative bill to the DMCA to provide for a minimalist implementation of the digital copyright treaties. See Digital Era Copyright Enhancement Act, H.R. 3048, 105th Cong. (1998).

50. See JAMES LARDNER, FAST ForwARD: HollywoOd, THE JAPANESE AND THE ONSLAUGHT OF THE VCR (1987).

51. Audio Home Recording Act, Pub. L. No. 102-563, 106 Stat. 4237 (1992) (now codified at 17 U.S.C. $\$ \S 1001-10$ ). The exemption for noncommercial copying of analog and some digital sound recordings is codified $I d$. $\S 1008$. Congress also passed the Fairness in Music Licensing Act that expanded an existing exception allowing commercial establishments to play music without paying royalties to copyright owners in the music. See Pub. L. No. 105298 (1998) (codified at 17 U.S.C. § 110(5)).

52. Senator Hatch has expressed concern about this and held hearings on digital music services. See, e.g., U.S. Senate Judiciary Committee, Hearings on "Music on the Internet: Is There an Upside to Downloading?," available at http://www.senate.gov/ judiciary/ wl7112000.htm. Senator Hatch's statement at that hearing on July 11, 2000, can be found at http://www.senate.gov/ judiciary/711200_ogh.htm.

53. See Declan McCulloch, New Copyright Bill Heading to DC, WIRED NEws, Sept. 7, 2001, available at http://www.wired.com/news/politics/0,1283,46655,00.html (discussing the Security Systems Standards and Certification Act ("SSSCA") that would mandate installation of standard technical protection measures in all interactive digital devices). 
determined that the member firms of the Recording Industry Association of America ("RIAA") or MPAA were engaging in anticompetitive conduct in the development or distribution of new digital entertainment products and instituted lawsuits challenging this conduct as a violation of the antitrust laws; the industry's control over the policy process would be lessened: ${ }^{54}$ A similar result would flow from a possible Federal Trade Commission charge that some of these firms were engaging in unfair trade practices. ${ }^{55}$ Even in the absence of such developments, it is surely true that the entertainment industry does not enjoy the same level of support from the Bush administration as it had from the Clinton administration. There is, moreover, reason to think that some Bush administration officials - notably John Ashcroft - may support more balanced copyright policies. ${ }^{56}$

Courts may also have a role to play in protecting the public interest in digital copyright law. This can happen in several ways. Courts may decide that existing law does not reach as far as copyright owners assert; that some new limiting principles are needed for copyright law to achieve its purposes; or that constitutional limitations preclude construing the law to reach certain conduct. Sony Betamax is the bestknown example of the first category,$^{57}$ but several digital copyright decisions may be cited as well, including Galoob $v$. Nintendo, ${ }^{58}$ Lotus $v$. Borland ${ }^{59}$ and $R I A A$ v. Diamond Multimedia.$^{60}$ Computer Associates v. Altai,$^{61}$ Sega v. Accolade, ${ }^{62}$ and Religious Technology Center v. Net-

54. See Laura M. Holson \& Rick Lyman, U.S. Inquiry is Raising Speculation in Hollywood, N.Y. TIMES, Dec. 29, 2001, at C1 (reporting on investigation into possible anticompetitive conduct by motion picture studios as to online movie services).

55. The European Union has been investigating whether the country-coding of DVD movies is a device to overprice DVDs. See, e.g., European Union Probes DVD Pricing, SAN JOSE MERC. NEWS, June 12, 2001, at 3G.

56. When Ashcroft was Attorney General for the state of Missouri, he filed an amicus brief in support of Sony in the Betamax case. Ashcroft was also the Senate sponsor of an alternative bill to the DMCA.

57. Sony Corp. of Am. v. Universal City Studios, Inc., 464 U.S. 417 (1984) (holding that movie studios were not entitled to control sale of videotape recorders because machines had substantial noninfringing uses).

58. Lewis Galoob Toys, Inc. v. Nintendo of Am., 964 F.2d 965 (9th Cir. 1992) (holding that it was not contributory infringement to sell Game Genie program so users could change the play of Nintendo games).

59. Lotus Dev. Corp. v. Borland Int'l, 49 F.3d 807 (1st Cir. 1995), aff'd by an equally divided Court, 516 U.S. 233 (1996) (holding that the command hierarchy of Lotus 1-2-3 was not protectable by copyright law because it was a method of operating a computer).

60. Recording Indus. Ass'n of Am. v. Diamond Multimedia, 180 F.3d 1072 (9th Cir. 1999) (ruling that the Audio Home Recording Act did not require the maker of the MP3 player to install anti-copying technology).

61. Computer Assocs. Int'l v. Altai, Inc., 982 F.2d 693 (2d Cir. 1992) (holding that elements of programs necessary to achieve compatibility are unprotectable by copyright law). 
$c^{\circ} m^{63}$ are examples of the second category. Campbell v. Acuff-Rose ( $^{64}$ and Feist $v$. Rural Telephone ${ }^{65}$ may be examples of the third. In several of these cases, the fair use defense proved to be the kind of flexible balancing rule that Litman endorses for copyright law in the information age..$^{66}$

Of course, counter-examples exist as well. The most pernicious decision on digital copyright issues - one that Litman has previously written about but scarcely mentions in this book - is the Ninth Circuit's decision in $M A I v$. Peak, ${ }^{67}$ which held that software copyrights could be infringed when an unlicensed person turned on a licensed firm's computer, thereby booting all the software in the system. This was not only a wrong decision on the merits, ${ }^{68}$ but its underlying premise - that temporary copies of copyrighted material in the random access memory of a computer infringe the reproduction right inadvertently provided copyright industries and the Clinton Administration with one of the central tenets of the new high protectionism: that any access to or use of a copyrighted work in digital form infringes the reproduction right unless authorized. ${ }^{69}$ As mentioned

62. Sega Enters. Ltd. v. Accolade, Inc., 977 F.2d 1510 (9th Cir. 1992) (holding that it is fair use to make intermediate copies of computer programs for a legitimate purpose, such as trying to make a compatible program).

63. Religious Tech. Ctr. v. Netcom, 907 F. Supp. 1361 (N.D. Cal. 1995) (holding that online service provider was not contributorily or vicariously liable for copyright infringement committed by a user prior to receiving notice of infringement).

64. Campbell v. Acuff-Rose Music, Inc., 510 U.S. 569 (1994) (stressing importance of criticism and parody to ongoing creativity which copyright and the First Amendment are intended to bring about).

65. Feist Pubs., Inc. v. Rural Tel. Service, 499 U.S. 340 (1991) (raising constitutional as well as statutory objections to claim that white pages listings of telephone directories could be copyrighted).

66. This includes Campbell v. Acuff-Rose, 510 U.S. 569 (fair use to parody "Pretty Woman" song); Sony-Betamax, 464 U.S. 417 (fair use to make time-shifting copies of broadcast television shows); Sega v. Accolade, 977 F.2d 1510 (fair use to decompile a program for purposes of making a compatible program); Galoob v. Nintendo, 964 F.2d 965 (fair use to use Game Genie program to alter the play of Nintendo games); RTC v. Netcom, $907 \mathrm{~F}$. Supp. 1361 (fair use analysis reinforced ruling against contributory liability for online service provider for user infringement). See also Pamela Samuelson, Fair Use For Computer Programs and Other Copyrightable Works in Digital Form: The Implications of Sony, Galoob and Sega, 1 J. INTELL. PROP. L. 49 (1993) (discussing implications of these decisions for many uses of digital information).

67. MAI Sys. Co. v. Peak Computer, Inc., 991 F.2d 511 (9th Cir. 1993). Litman has criticized this decision. See Jessica Litman, The Exclusive Right to Read, 13 CARDozo ARTS \& ENT. L.J. 29 (1994).

68. The decision was so clearly incorrect that Congress legislatively overturned it. See Digital Millennium Copyright Act, Pub. L. No. 105-304, Title III, Sec. 302, 112 Stat. 2887 (1998), now codified at 17 U.S.C. $\$ 117$ (c); Litman, supra note 67; David Nimmer, Brains and Other Paraphenalia of the Digital Age, 10 HARV. J.L. \& TECH. 1 (1996). But see Ginsburg, supra note 21 (arguing that MAI v. Peak was correctly decided).

69. See White Paper, supra note 22, at 64-65. 
above, the WIPO Copyright Treaty rejected this view. ${ }^{70}$ Moreover, U.S. caselaw does not support the view that the reproduction right provides copyright owners with an exclusive right to control all uses of copyrighted information.

There are, of course, some repeat-player advantages for copyright industries in the courts just as there are in the legislature, ${ }^{71}$ but it is too soon to give up on judicial rulings as a means for achieving a better balance in digital copyright law. One advantage of becoming a more senior scholar in the intellectual property field is seeing the ebb and flow of decisions on new technology issues. I was once dismayed by the first round of software copyright decisions that were highly protectionist for substantially the same reason, in my view, that courts have sometimes construed copyright law very broadly in digital copyright cases: concern about the impact that decisions limiting the scope of protection might have for the viability of the affected industry. ${ }^{72}$ Over time, the software copyright decisions became more moderate in tone and substance as courts recognized the negative consequences for competition, innovation, and the public interest that would flow result from highly protectionist rules. Perhaps a similar pattern may emerge in the digital copyright caselaw in the $2000 \mathrm{~s}$.

\section{CONCLUSION}

For more than two hundred years, the United States has consciously adopted a plethora of information policies aimed at promoting the generation of useful information, its widespread dissemination, and freedoms to use information both privately and publicly. It has done so through a wide array of mechanisms, including passage of copyright laws, but also by support for public education and libraries; support for basic science; governmental collection and publication of information (e.g., census and weather data, laws and judicial opin-

\section{See supra note 43 .}

71. See, e.g., Lunney, supra note 6, at 901-02; Neil W. Netanel, Locating Copyright Within the First Amendment Skein, 54 STAN. L. REV. 1, 67-69 (2001).

72. See, e.g., Whelan Assocs., Inc. v. Jaslow Dental Lab., Inc., 797 F.2d 1222 (3d Cir. 1986), cert. denied, 479 U.S. 1031 (1987) (extending copyright protection to the structure, sequence and organization of computer programs so that the software industry would be adequately protected; announcing a very broad test for software copyright infringement). Numerous cases initially endorsed Whelan's approach to analyzing software copyright infringement. See, e.g., Johnson Controls, Inc., v. Phoenix Control Sys., Inc., 886 F.2d 1173 (9th Cir. 1989); Lotus Dev. Corp. v. Paperback Software, Inc., 740 F. Supp. 37 (D. Mass. 1990). The turning point in this line of cases was the Second Circuit's decision in Computer Assocs. Int'l v. Altai, Inc., 982 F.2d 693 (2d Cir. 1992) (rejecting Whelan's broad test for copyright infringement as well as the same economic argument for broad copyright protection for software; announcing a narrower test for copyright infringement). The Altai test displaced the Whelan test in subsequent cases. See, e.g., Bateman v. Mnemonics, Inc., 79 F.3d 1532 (11th Cir. 1996); Gates Rubber Co. v. Bando Chem. Indus., 9 F.3d 823 (10th Cir. 1993); Sega Enter. Ltd. v. Accolade, Inc., 977 F.2d 1510 (9th Cir. 1992). 
ions); subsidized mailing rates for newspapers, magazines, and books; freedom of information laws; and broadcast regulations, to name just a few. Many of the freedoms Americans hold dear - including freedom to send and receive information, and to express and publish one's ideas - depend on a supporting infrastructure of enlightened information policies.

Copyright has played an important role in this enlightened information policy. By providing reassurance that authors could benefit from the commercial value of their works, copyright law successfully promoted the creation and dissemination of many works of authorship, just as the Founders hoped. This is a function for copyright law that Litman would preserve. But limitations on the scope of rights are also important in promoting enlightened information policy. ${ }^{73}$ The 1976 Act, for example, forbids copyright protection for ideas and information in protected works ${ }^{74}$ grants rights to control certain public although not private uses of the works ${ }^{75}$ and privileges fair uses and redistribution of purchased copies (the latter making libraries and bookstores legal). ${ }^{76}$

Digital Copyright explains how and why some of these limiting doctrines have been eroding and why the public should care. Litman points out that "[t]he current digital copyright agenda seeks to supply copyright answers to a whole range of basic policy questions ranging from who is entitled to access, to what, and on whose terms, to whether citizens have any private interest whatsoever in personal data" (p. 28). Litman would address those questions head-on, but would provide quite different answers than the copyright industries. She senses that basic freedoms are at stake and wants to assure their preservation. Unfortunately, the chances of reforming copyright law and the copyright policy process seem dim unless the public once again becomes engaged in copyright issues and takes action to insist

73. In other writings, Litman has emphasized the importance of copyright limitations in promoting enlightened information policy. See, e.g., Jessica Litman, Copyright and Information Policy, 55 LAw \& CONTEMP. PROBS. 185 (1992); Jessica Litman, The Public Domain, 39 EMORY L.J. 965 (1990).

74. 17 U.S.C. $\S 102$ (b) (2000) ("In no case does copyright protection for a work of authorship extend to any idea, process, procedure, system, method of operation, principle, concept or discovery, regardless of how it is embodied in the work.") The "idea/expression" distinction predates the Copyright Act of 1976 , but the 1976 Act was the first copyright statute to embody this distinction and expressly provide that processes, procedures, systems and methods of operation were beyond the scope of copyright protection. So although the 1976 Act broadened copyright protection in some respects, see supra note 14 and accompanying text, it also contained important limitations on copyright protection. See id. $\S 103$ (copyright in compilation of facts does not extend to preexisting data).

75. Id. \$ 106(3)-(5); see also supra notes 19-20 and accompanying text.

76. 17 U.S.C. $\S \S 107$ (fair use); 109 (first sale limitation) (2000). The nonstatutory doctrine of copyright misuse also limits the power of copyright owners in exercising their rights. See, e.g., Mark A. Lemley, Beyond Preemption: The Law and Policy of Intellectual Property Licensing, 87 CAL. L. REV. 111 (1999). 
on changes. Litman surely hopes that her book will be both a wakeup call and a call to action.

Litman implicitly aims her argument not just at the slumbering public (whom she must know will be disinclined to buy or read a book on digital copyright law, let alone to demand immediate Congressional action), but also at copyright professionals - and possibly even to members of Congress and their staffs - who have reason to worry that the public simply will not abide by stringent copyright rules even if industry groups are able to persuade Congress to enact and the courts to enforce them. Wouldn't it be better, she asks, to have a simpler, more coherent, and more balanced law that people would actually respect than to have the engorged law of your dreams that no one but you can understand or is willing to abide by?

Litman might have done more to formulate strategies for reforming the copyright policy process, but by writing Digital Copyright, she has done a great service in translating the arcana of copyright law into plain English, in masterfully explicating the breakdown of the copyright policy process, and in re-conceptualizing copyright law for an information age. A new and fairer deal for copyright is achievable and worth the effort necessary to bring it about. Excessive copyright protection impedes the progress of science, and contravenes the Enlightenment policy embodied in the Constitution. Digital technology may have disrupted the old copyright balance, but that doesn't mean that balance is no longer necessary, as some copyright industry groups seem to believe. The balance simply needs to be recalibrated. Public interest limitations on copyright also need to be more clearly expressed. Digital Copyright provides useful guidance on how to achieve these important goals. We ignore the lessons it teaches at our peril. 